\title{
Genetic aspects of susceptibility to air pollution
}

\author{
S.R. Kleeberger
}

Genetic aspects of susceptibility to air pollution. S.R. Kleeberger. C ERS Journals Ltd 2003.

ABSTRACT: Inter-individual variation in human responses to air pollutants suggests that some subpopulations are at increased risk, and it is increasingly clear that genetic background is an important susceptibility factor.

Genetically standardised animal models provide useful investigative tools. Linkage analyses using inbred mice identified chromosomal segments (quantitative trait loci (QTL)), with genes controlling susceptibility to the lung inflammatory (chromosome 17), injury (chromosome 11), and hyperpermeability (chromosome 4) responses to ozone $\left(\mathrm{O}_{3}\right)$ exposure. An immune dysfunction response induced by exposure to sulphateassociated particles is linked to the identical chromosome 17 and 11 QTLs described for $\mathrm{O}_{3}$ susceptibility, thus similar genetic mechanisms may be controlling pulmonary responses to these pollutants. Candidate genes within the QTLs on chromosomes 4 and 17 include the toll-like receptor 4 and the pro-inflammatory cytokine, tumour necrosis factor- $\alpha$, respectively. Functional analyses strongly support a role for these candidate genes in determining susceptibility to $\mathrm{O}_{3}$ and particulates. Because striking linkage homology exists between the human and mouse genomes, candidate susceptibility genes identified in the mouse are likely to aid research aimed at understanding human genetic factors that contribute to differential susceptibility.

To date, no studies have examined the interaction between age and genetic background in the development of air pollution-induced lung disease. However, investigations have suggested an influence of age on genetic susceptibility to lung cancer and other diseases, which indicate that an interaction between age and genetic background may be important in air pollution disease pathogenesis.

Eur Respir J 2003; 21: Suppl. 40, 52s-56s.
Dept of Environmental Health Sciences, Bloomberg School of Public Health, Johns Hopkins University, Baltimore, MD, USA.

Correspondence: S.R. Kleeberger, Laboratory of Pulmonary Pathobiology, National Institute of Environmental Health Sciences, National Institutes of Health, 111 T.W. Alexander Dr, Building 101, Rm. D240, Research Triangle Park, NC 27709, USA.

Fax: 19195414133

E-mail: kleeber1@niehs.nih.gov

Keywords: Innate immunity, ozone, particles, polymorphism, toll-like receptor 4 , tumour necrosis factor- $\alpha$

Received and accepted: April 122002

The author was supported by grants from the National Institutes of Health (HL57142, ES09606, and P30 ES00002) and the Environmental Protection Agency (R826724).
Air pollution continues to be an important public health and economic concern in industrialised cities throughout the world. Numerous epidemiological associations of adverse health outcomes with air pollution episodes support these concerns. Inter-individual variation in human responses to air pollutants indicates that not all individuals exposed to pollutants respond similarly. That is, some subpopulations are at increased risk to the detrimental effects of pollutant exposure. The United States Clean Air Act specifies that primary National Ambient Air Quality Standards for criteria pollutants be set low enough to protect the health of all susceptible groups within the population. Exceptions include those requiring life-support systems, intensive care unit patients, and newborn infants in nurseries. However, identification of those factors that determine susceptibility continues to be elusive.

Broadly, inter-individual variation in biological responses to environmental stimuli is a consequence of internal and external factors. External factors include physical forces (e.g. temperature, altitude), socioeconomic status, and previous exposure. Internal factors include sex, age, diet, and predisposing disease (e.g. asthma). Genetic background has become increasingly recognised as another important internal or host factor in environmental disease predisposition. In human populations, gene polymorphisms have been associated with susceptibility to environmental agents including pesticides and infectious agents [1-3].

It is also clear that multiple internal and external factors contribute to individual responses to air pollutants. A number of populations have been identified that are particularly susceptible to the toxic effects of airborne oxidants and particulates, including the elderly and individuals with cardiopulmonary disease [4, 5]. Evidence also exists for genetic determinants of susceptibility to airborne pollutants, including ozone $\left(\mathrm{O}_{3}\right)$ and particulates (see below). The primary objective of this manuscript is to discuss briefly studies that have identified a genetic basis for susceptibility to air pollution in animal models and human subjects, and the approaches used to identify susceptibility genes.

\section{Research strategies employed to identify candidate genes}

Two broad research strategies have been utilised to identify genes (quantitative trait loci (QTLs)) that determine susceptibility. The first is a genome scan or positional cloning (formerly known as reverse genetics). This strategy attempts to associate expression of genes or markers (e.g. microsatellite markers, see below) with phenotype(s) in segregant populations. A genome-wide screen is designed to identify linkage to any chromosomal intervals within the entire genome that may contain genes that are polymorphic between two strains of mice and may account for the differential response phenotype under study. That is, no a priori hypothesis about the role of a specific gene or genes is tested. This is ideally suited for genetically well-controlled models, particularly inbred mice, but is applicable to human populations as well. The second research strategy is the candidate gene approach (formerly 
"forward genetics"), in which genes are chosen a priori as likely mechanisms that determine the phenotype of interest. With the candidate gene approach, linkage is then assessed between the phenotype of interest and markers flanking the candidate genes or the candidate genes themselves. This strategy may implicate certain genes in the expressed phenotype. However, without a genome scan, the candidate gene approach may exclude other important loci that determine a quantitative trait, as well as the interaction between them. These strategies, alone or in combination, have been utilised in inbred mice to identify genetic mechanisms of a number of diseases. These include models of Huntingtons disease [6, 7], Duchenne muscular dystrophy [8], amyotrophic lateral sclerosis [9], insulindependent diabetes mellitus [10], Alzheimer's disease [11], von Willebrand disease [12], chronic granulomatous disease [13], and Niemann-Pick C1 disease [14]. The considerable resources and energy applied to mapping of the mouse genome as an integral component of the Human Genome Project underlie the importance of this animal model for human diseases [15]. One of the unifying concepts for genetic studies in mice is the linkage relationship of homologous loci from human and mouse. Specifically, highly significant homologies in gene order and chromosomal structure have been maintained between mice and humans since their divergence [16]. Therefore, identification of the chromosomal location of a susceptibility gene in the mouse provides the basis for potentially localising a homologous gene in the human $[17,18]$.

\section{Candidate genes for susceptibility to air pollutants}

Identification of a QTL is a multi-step process that may be broadly grouped into three research objectives. The first objective is to determine whether the response phenotype is genetically determined and quantitative. After determining that the quantitative phenotype has a genetic basis, then the susceptibility QTL(s) are sought. Finally, significant informative QTLs are searched for candidate genes that may explain differential susceptibility/responsiveness in the model. It is beyond the scope of this manuscript to explain all of the details of linkage mapping; therefore, the reader is referred to excellent reviews of this topic by BROMAN [19], MOORE and NAGLE [20], and Silver [21]. Selected investigations that have led to the identification of susceptibility QTLs for $\mathrm{O}_{3}$ - and particle-induced pulmonary inflammation and injury are described below. This discussion is not exhaustive, and it is meant only to illustrate the approach to identify the genetic basis of susceptibility to air pollutants as well as candidate genes that may be important determinants of susceptibility.

\section{Genetic determinants of susceptibility to ozone-induced lung inflammation and injury}

$\mathrm{O}_{3}$ exposure induces multiple pulmonary and extrapulmonary responses in humans and animal models. $\mathrm{O}_{3}$ elicits inflammation, hyperreactivity and epithelial damage of the airways, as well as altered ventilation and decrements in pulmonary function $[4,22] . \mathrm{O}_{3}$ has also been demonstrated to either suppress or enhance immune responsiveness [23]. Significant inter-strain variation in the magnitude of these responses has also been demonstrated in rats and mice, and has thus provided strong evidence of a genetic component to $\mathrm{O}_{3}$ responsiveness [24-26].

The inter-strain variation in susceptibility among inbred mice led the author's laboratory to conduct studies to identify the chromosomal location of the $\mathrm{O}_{3}$ susceptibility genes using susceptible $\mathrm{C} 57 \mathrm{BL} / 6 \mathrm{~J}$ (B6) and resistant $\mathrm{C} 3 \mathrm{H} / \mathrm{HeJ}$ (C3) strains. A genome-wide search for linkage of the inflammation (polymorphonuclear leukocytes) phenotype was performed with informative simple sequence length polymorphisms (SSLPs) distributed at $\sim 10$-centi-Morgan (cM) intervals throughout the genome (see [27] for more detail regarding choice of markers). The number and spacing of markers yielded complete coverage of the mouse genome with $95 \%$ confidence. Linkage was carried out with individual intercross animals derived from $\mathrm{B} 6$ and $\mathrm{C} 3$ progenitors $\left(\mathrm{B} 6 \mathrm{C} 3 \mathrm{~F}_{2}\right)$. The phenotyped $\mathrm{F}_{2}$ progeny were genotyped for each of the SSLPs, and linkage of susceptibility to $\mathrm{O}_{3}$ was evaluated using Map Manager QT and MAPMAKER-QTL software packages. Interval mapping by simple linear regression in the entire $\mathrm{F}_{2}$ cohort determined the presence of a susceptibility locus on chromosome 17 in the interval $\sim 16-22 \mathrm{cM}$ (table 1 ; [27]). An additional QTL was detected on chromosome 11 between D11Mit20 and D11Mit12. Within the chromosome 17 QTL, there are a number of candidate genes, including the pro-inflammatory cytokine, tumour necrosis factor (TNF)- $\alpha$. Because TNF- $\alpha$ may be postulated to have a role in the inflammatory response to oxidant-related lung injury, preliminary evaluations of this candidate gene were made for determination of differential $\mathrm{O}_{3}$-induced inflammation in $\mathrm{B} 6$ and C3 mice. Pretreatment of susceptible B6 mice with a

Table 1.-Linkage and association studies that have identified quantitative trait loci (QTLs) and/or candidate genes for susceptibility to detrimental effects of air pollutants on the lung

\begin{tabular}{|c|c|c|c|c|c|c|}
\hline Study type & Species & Pollutant & Phenotype & $\begin{array}{l}\text { Chromosomal } \\
\text { location(s) of QTLs }\end{array}$ & Candidate gene & First author [ref no.] \\
\hline
\end{tabular}

\begin{tabular}{|c|c|c|c|c|c|c|}
\hline \multirow[t]{4}{*}{ Linkage } & Mouse & Ozone & Inflammation (PMNs) & $\begin{array}{l}17 \\
11\end{array}$ & $\begin{array}{c}\text { TNF- } \alpha \\
\text { Small inducible cytokines }\end{array}$ & KLEeberGer [27] \\
\hline & Mouse & Ozone & Lung hyperpermeability & $\begin{array}{c}4 \\
11\end{array}$ & $\begin{array}{c}\text { TLR4 } \\
\text { Small inducible cytokines }\end{array}$ & KLEEBERGER [28] \\
\hline & Mouse & Ozone & Acute lung injury, death & $\begin{array}{l}11 \\
13 \\
17\end{array}$ & $\begin{array}{c}\text { Small inducible cytokines } \\
\text { GPX } \\
\text { TNF- } \alpha, \text { XDH }\end{array}$ & Prows [26] \\
\hline & Mouse & $\begin{array}{l}\text { Sulphate-associated } \\
\text { particles }\end{array}$ & Immune dysfunction & 17 & TNF- $\alpha$ & OHTSUKA [29] \\
\hline Association & Human & Ozone & $\begin{array}{l}\text { Pulmonary dysfunction, } \\
\text { lung hyperpermeability }\end{array}$ & $\begin{array}{c}11 \\
\text { N/A }\end{array}$ & $\begin{array}{l}\text { Small inducible cytokines } \\
\text { NQO1; GSTM1 }\end{array}$ & BERGAMASCHI [30] \\
\hline
\end{tabular}

GSTM1: glutathione-S-transferase $\mu-1$; GPX: glutathione peroxidase; NQO1: nicotinamide adenine dinucleotide phosphate $(\mathrm{NAD}(\mathrm{P}))$ : quinone oxidoreductase; TLR4: toll-like receptor 4; TNF- $\alpha$ : tumour necrosis factor $\alpha$; XDH: xanthine dehydrogenase; $\mathrm{O}_{3}$ : ozone; PMN: polymorphonuclear leukocytes; N/A: not applicable. 
monoclonal antibody to TNF- $\alpha$ significantly attenuated the inflammatory response to $\mathrm{O}_{3}$ relative to control $\mathrm{B} 6$ mice, thus providing support of TNF- $\alpha$ as a candidate susceptibility gene in this model [27].

To further understand the mechanisms of $\mathrm{O}_{3}$-induced lung injury, a genome-wide linkage analysis for susceptibility QTLs was performed to explain inter-strain differences in hyperpermeability induced by $72-\mathrm{h}$ exposure to 0.3 parts per million (ppm) $\mathrm{O}_{3}$. Because there is an apparent dissociation between inflammatory cell infiltration and lung hyperpermeability induced by $\mathrm{O}_{3}$ [31], it was hypothesised that different loci control the hyperpermeability response. To determine the susceptibility QTLs, a genome screen was performed using recombinant inbred (RI) strains of mice derived from B6 and C3 progenitors (see [21] for explanation of the use of RIs for QTL mapping). A significant QTL was identified on chromosome 4, and suggestive QTLs were identified on chromosomes 3 and 11 (table 1; [28]). The chromosome 4 QTL contains a candidate gene, toll-like receptor 4 (TLR4) that has recently been implicated in innate immunity and endotoxin susceptibility [32-34]. As a "proof of concept" that TLR4 has an important functional role in susceptibility, the hyperpermeability responses to $\mathrm{O}_{3}$ in $\mathrm{C} 3 \mathrm{H} / \mathrm{HeOuJ}(\mathrm{OuJ})$ and C3 mice were compared. These strains differ only at a polymorphism in the coding region of the TLR4 gene and the polymorphism confers resistance to endotoxin-induced injury in the C3 mouse compared to wild type OuJ. Significantly greater protein concentrations were found in $\mathrm{OuJ}$ mice compared with $\mathrm{C} 3$ mice after exposure to $\mathrm{O}_{3}$ [28]. Furthermore, reverse transcriptase polymerase chain reaction analysis demonstrated that TLR4 message levels in the lungs of C3 mice were markedly downregulated, while levels increased in the OuJ strain after $\mathrm{O}_{3}$ exposure [28]. Together, results indicate that a QTL on chromosome 4 explains a significant portion of the genetic variance in $\mathrm{O}_{3}$-induced hyperpermeability, and support a role for TLR4 as a strong candidate susceptibility gene. This is the first demonstration that innate immune mechanisms modulated by TLR 4 are involved in the pulmonary response to oxidant exposure.

PROws et al. [26] performed a linkage analysis of susceptibility to death induced by exposure to high concentrations of $\mathrm{O}_{3}$. Using susceptible $\mathrm{A} / \mathrm{J}$ and resistant $\mathrm{B} 6$ mice, these investigators identified a significant QTL on chromosome 11, and suggestive QTLs on chromosomes 13 and 17 (table 1). Interestingly, the QTLs on chromosomes 11 and 17 are similar to those described by KLEEBERGER et al. [27] for susceptibility to inflammation induced by exposure to $0.3 \mathrm{ppm}$ $\mathrm{O}_{3}$.

Evidence also exists for genetic determinants of susceptibility to $\mathrm{O}_{3}$ in human subjects. A number of laboratories have reported inter-individual variation in pulmonary function responses to $\mathrm{O}_{3}$ in otherwise normal, healthy human subjects [35-37]. Inter-individual variation in the inflammatory response to $\mathrm{O}_{3}$ has also been described [38-42]. A second line of evidence is the demonstration that specific gene polymorphisms associate with response phenotypes in exposed human subjects. BERGAMASCHI et al. [30] found that polymorphisms in genes for quinone-metabolising enzymes may have an important role in the pulmonary function and epithelial permeability responses to $\mathrm{O}_{3}$ in nonsmoking exercising subjects.

\section{Genetic determinants of susceptibility to particle-induced lung inflammation and injury}

Considerable attention has been focused on the adverse respiratory effects caused by inhalation of particles. Epidemiological studies have reported significant association of acute and chronic respiratory and nonrespiratory health effects with increases in particulate exposure throughout the industrialised world [4, 43, 44]. Susceptible subpopulations include the aged $(\geqslant 65 \mathrm{yrs})$ and patients with cardiopulmonary disease, such as chronic heart disease, chronic obstructive pulmonary disease, and asthma [4, 45-47]. To determine whether genetic background is an important determinant of pulmonary responses to particulates, the inter-strain variance of lung responses to acid sulphate-coated particles (ACP) in inbred strains of mice was studied [48]. Although the 4-h challenge to ACP did not elicit a detectable inflammatory response, significant inter-strain differences were found in Fc receptor-mediated phagocytosis of alveolar macrophages (an indicator of innate immune defence). A genome scan similar to that described for $\mathrm{O}_{3}$ susceptibility (see above) was then performed with susceptible B6 and resistant C3 mice [29]. Interestingly, linkage analyses identified a significant QTL on chromosome 17 and a suggestive QTL on chromosome 11 that nearly overlapped similar QTLs identified for $\mathrm{O}_{3}$ susceptibility. The common linkages suggest that similar genetic mechanisms may control pulmonary responses to $\mathrm{O}_{3}$-induced inflammation and macrophage phagocytic dysfunction induced by ACP; however, further genetic analyses are required to confirm this hypothesis.

\section{Contribution of age and genetic susceptibility to airborne pollutants}

To date, few studies have examined the influence of age on genetic susceptibility to pulmonary diseases, and none have examined the interaction of these host factors on pollutant susceptibility. GAUDERMAN and MORRISON [49] performed a segregation analysis suggesting that the effect of genotype on lung cancer varies by age, such that age-specific relative risks are greatest in the young and decline thereafter. Though no specific genes were identified, this study strongly suggests that age and genetic background may be important co-determinants of pulmonary disease. Both factors should be considered in future proposals/studies to understand susceptibility to air pollutant-induced lung disease.

\section{Conclusion}

Air pollution-induced morbidity and mortality continue to be important public health concerns worldwide, and identification of susceptible subpopulations is of critical importance. Numerous factors may contribute to inter-individual susceptibility to the detrimental effects of air pollution, including age and genetic background. Linkage analyses with inbred mice and association studies with human subjects have led to identification of candidate susceptibility genes for pulmonary responses to ozone and sulphate-associated particles. The role of age as an interacting factor with genetic background has not been thoroughly examined in air pollution-induced lung disease, but likely has an important role in genetic susceptibility, and future studies should be designed to investigate the interaction of these two factors. An understanding of the biology of candidate genes will lead to an understanding of the genetic basis for differential responses to pollutant exposures. Furthermore, characterisation of a polymorphism in a pollutant susceptibility gene(s) may thus provide the means to identify individuals who are genetically susceptible to the development of injury. 


\section{References}

1. Calabrese EF. Ecogenetics: Genetic Variation in Susceptibility to Environmental Agents. New York, Wiley, 1984.

2. Grandjean P. Ecogenetics: Genetic Predisposition to the Toxic Effects of Chemicals. London, Chapman and Hall, 1991.

3. Omenn GS, Motulsky AG. Ecogenetics: Genetic variation in the susceptibility to environmental agents. In: Cohen $\mathrm{BH}$, Lilienfeld AM, Huang PC, eds. Genetic Issues in Public Health and Medicine. Springfield, IL, CC Thomas, 1978; pp. 83-111.

4. Bascom R, Bromberg PA, Costa DA, et al. Health effects of outdoor air pollution. Committee of the Environmental and Occupational Health Assembly of the American Thoracic Society. Am J Respir Crit Care Med 1996; 153: 3-50.

5. Calabrese EF. Pollutants and High Risk Groups. New York, Wiley, 1978.

6. Mangiarini L, Sathasivam K, Seller M, et al. Exon 1 of the HD gene with an expanded CAG repeat is sufficient to cause a progressive neurological phenotype in transgenic mice. Cell 1996; 87: 493-506.

7. Nasir J, Lin B, Bucan M, Koizumi T, Nadeau JH, Hayden MR. The murine homologues of the Huntington disease gene $(H d h)$ and the a-adducin gene $(A d d l)$ map to mouse chromosome 5 within a region of conserved synteny with human chromosome 4p16.3. Genomics 1994; 22: 198201.

8. Brockdorff N, Cross GS, Cavanna JS, et al. The mapping of a cDNA from the human X-linked Duchenne muscular dystrophy gene to the mouse X chromosome. Nature 1987; 328: 166-168.

9. Brown RH Jr. Amyotrophic lateral sclerosis: recent insights from genetics and transgenic mice. Cell 1995; 80: 687-692.

10. Morahan G, Huang D, Tait BD, Colman PG, Harrison LC. Markers on distal chromosome $2 \mathrm{q}$ linked to insulindependent diabetes mellitus. Science 1996; 272: 1811-1813.

11. Levy-Lahad E, Wasco W, Poorkaj P, et al. Candidate gene for the chromosome 1 familial Alzheimer's disease locus. Science 1995; 269: 973-977.

12. Ginsburg D, Bowie EJ. Molecular genetics of von Willebrand disease. Blood 1992; 79: 2507-2519.

13. Jackson SH, Gallin JI, Holland SM. The p47phox mouse knock-out model of chronic granulomatous disease. $J$ Exp Med 1995; 182: 751-758.

14. Carstea ED, Morris JA, Coleman KG, et al. Niemann-Pick C1 disease gene: homology to mediators of cholesterol homeostasis. Science 1997; 277: 228-231.

15. Brown SDM. The mouse genome project and human genetics. Genomics 1992; 13: 490-492.

16. Mouse Genome Sequencing Consortium. Initial sequencing and comparative analysis of the mouse genome. Nature 2002; 420: $520-562$.

17. Jacob CO, Mykytyn K, Varcony T, Drabkin HA. Mapping of the interleukin-5 receptor gene to human chromosome 3p25-p26 and to mouse chromosome 6 close to the Raf-1 locus with polymorphic tandem repeat sequences. Mamm Genome 1993; 4: 435-443.

18. Kim JM, Brannan CI, Copeland NG, Jenkins NA, Khan TA, Moore KW. Structure of the mouse IL-10 gene and chromosomal localization of the mouse and human genes. J Immunol 1992; 148: 3618-3623.

19. Broman KW. Review of statistical methods for QTL mapping in experimental crosses. Lab Animal 2001; 30: 44 52.

20. Moore KJ, Nagle DL. Complex trait analysis in the mouse: the strengths, the limitations and the promise yet to come. Annu Rev Genet 2000; 34: 653-686.

21. Silver LM. Mouse Genetics. Concepts and Applications. New York, Oxford University Press, 1995.

22. Kleeberger SR. Genetic susceptibility to ozone exposure. Toxicol Lett 1995; 82/83: 295-300.
23. Jakab GJ, Spannhake EW, Canning BJ, Kleeberger SR, Gilmour MI. The effects of ozone on immune function. Environ Health Perspect 1995; 103: Suppl. 2, 77-89.

24. Kleeberger SR, Bassett DJ, Jakab GJ, Levitt RC. A genetic model for evaluation of susceptibility to ozone-induced inflammation. Am J Physiol 1990; 258: L313-L320.

25. Kleeberger SR, Levitt RC, Zhang LY, et al. Susceptibility to ozone-induced inflammation. I. Genetic control of the response to subacute exposure. Am J Physiol 1993; 264: L15L20.

26. Prows DR, Shertzer HG, Daly MJ, Sidman CL, Leikauf GD. Genetic analysis of ozone-induced acute lung injury in sensitive and resistant strains of mice. Nat Genet 1997; 17: 471-474.

27. Kleeberger SR, Levitt RC, Zhang LY, et al. Linkage analysis of susceptibility to ozone-induced lung inflammation in inbred mice. Nat Genet 1997; 17: 475-478.

28. Kleeberger SR, Reddy S, Zhang LY, Jedlicka AE. Genetic susceptibility to ozone-induced lung hyperpermeability. Role of toll-like receptor 4. Am J Respir Cell Mol Biol 2000; 22: 620-627.

29. Ohtsuka Y, Brunson KJ, Jedlicka AE, et al. Genetic linkage analysis of susceptibility to particle exposure in mice. Am J Respir Cell Mol Biol 2000; 22: 574-581.

30. Bergamaschi E, De Palma G, Mozzoni P, et al. Polymorphism of quinone-metabolizing enzymes and susceptibility to ozone-induced acute effects. Am J Respir Crit Care Med 2001; 163: 1426-1431.

31. Kleeberger SR, Hudak BB. Acute ozone-induced change in airway permeability: the role of infiltrating leukocytes. $J$ Appl Physiol 1992; 72: 670-676.

32. Kopp EB, Medzhitov R. The toll-receptor family and control of innate immunity. Curr Opin Immunol 1999; 11: 13-18.

33. Poltorak A, He X, Smirnova I, et al. Defective LPS signaling in $\mathrm{C} 3 \mathrm{H} / \mathrm{HeJ}$ and $\mathrm{C} 57 \mathrm{BL} / 10 \mathrm{ScCr}$ mice: mutations in the Tlr4 gene. Science 1998; 282: 2085-2088.

34. Qureshi ST, Lariviere L, Leveque G, et al. Endotoxintolerant mice have mutations in toll-like receptor 4 (Tlr4). J Exp Med 1999; 189: 615-625.

35. McDonnell WF. Intersubject variability in human acute ozone responsiveness. Pharmacogenetics 1991; 1: 110-113.

36. McDonnell WF, Horstman DH, Hazucha MJ, et al. Pulmonary effects of ozone exposure during exercise: doseresponse characteristics. J Appl Physiol 1983; 54: 1345-1352.

37. Weinmann GG, Bowes SM, Gerbase MW, Kimball AW, Frank R. Response to acute ozone exposure in healthy men. Results of a screening procedure. Am J Respir Crit Care Med 1995; 151: 33-40.

38. Aris RM, Christian D, Hearne PQ, Kerr K, Finkbeiner WE, Balmes JR. Ozone-induced airway inflammation in human subjects as determined by airway lavage and biopsy. Am Rev Respir Dis 1993; 148: 1363-1372.

39. Basha MA, Gross KB, Gwizdala CJ, Haidar AH, Popovich J Jr. Bronchoalveolar lavage neutrophilia in asthmatic and healthy volunteers after controlled exposure to ozone and filtered purified air. Chest 1994; 106: 1757-1765.

40. McBride DE, Koenig JQ, Luchtel DL, Williams PV, Henderson WR Jr. Inflammatory effects of ozone in the upper airways of subjects with asthma. Am J Respir Crit Care Med 1994; 149: 1192-1197.

41. Schelegle ES, Siefkin AD, McDonald RJ. Time course of ozone-induced neutrophilia in normal humans. Am Rev Respir Dis 1991; 143: 1353-1358.

42. Seltzer J, Bigby BG, Stulbarg M, et al. $\mathrm{O}_{3}$-induced change in bronchial reactivity to methacholine and airway inflammation in humans. J Appl Physiol 1986; 60: 1321-1326.

43. Pope CA III, Thun MJ, Namboodiri MM, et al. Particulate air pollution as a predictor of mortality in a prospective study of U.S. adults. Am J Respir Crit Care Med 1995; 151: 669-674.

44. Raizenne M, Neas LM, Damokosh AI, et al. Health effects 
of acid aerosols on North American children: pulmonary function. Environ Health Perspect 1996; 104: 506-514.

45. Schwartz J. What are people dying of on high air pollution days? Environ Res 1994; 64: 26-35.

46. Sunyer J, Anto JM, Murillo C, Saez M. Effects of urban air pollution on emergency room admissions for chronic obstructive pulmonary disease. Am J Epidemiol 1991; 134: 277-286.

47. Vedal S, Petkau J, White R, Blair J. Acute effects of ambient inhalable particles in asthmatic and nonasthmatic children. Am J Respir Crit Care Med 1998; 157: 1034-1043.

48. Ohtsuka Y, Clarke RW, Mitzner W, Brunson K, Jakab GJ, Kleeberger SR. Interstrain variation in murine susceptibility to inhaled acid-coated particles. Am J Physiol Lung Cell Mol Physiol 2000; 278: L469-L476.

49. Gauderman WJ, Morrison JL. Evidence for age-specific genetic relative risks in lung cancer. Am J Epidemiol 1999; 151: 41-49. 